\title{
Tilfelli mánaðarins Kona á fertugsaldri með kyngingarörðugleika og brjóstverki
}

Helena Árnadóttir ${ }^{1}$ læknir, Hallgrímur Guðjónsson² læknir, Margrét Sigurðardóttir ${ }^{3}$ meinafræðingur, Sigurður Blöndal ${ }^{4}$ læknir, Tómas Guðbjartsson ${ }^{4}$ læknir

\section{Tilfelli}

'Sjúkrahúsinu í Helsingborg í Svípjód, meltingarsjúkdómadeild,

${ }^{3}$ rannsóknarstofu i

meinafræði, 4hjarta- og lungnaskurðdeild

Landspítala Tómas Guðbjartson, hjarta- og lungnaskurðdeild

Landspítala

tomasgud@landspitali.is

Greinin barst 28. ágúst 2013, sampykkt til birtingar 23. október 2013.
Tæplega fertug kona leitaði til meltingarlæknis vegna margra ára sögu um vaxandi ópægindi við kyngingu ásamt verkjaónotum í brjóstkassa. Einkennum lýsti hún sem „lofti sem festist í brjóstkassanum“ og kyngingarörðugleikum við neyslu bæði fastrar og fljótandi fæðu. Hún hafði aldrei reykt, tók engin lyf og var almennt hraust. Gerð var magaspeglun og sást pá innbungun, í annars eðlilega vélindaslímhúð, $25 \mathrm{~cm}$ frá tanngarði. Tölvusneiðmyndir af brjóstholi sýndu $4 \times 2 \mathrm{~cm}$ fyrirferð í miðju miðmæti (mynd 1a). Vélindaómspeglun var framkvæmd í tvígang og tekin sýni úr æxlinu sem ekki gáfu greiningu. Sex mánuðum síðar var gerð segulómun af brjóstholi sem sýndi að fyrirferðin var hægt stækkandi (mynd 1b).

Hver er líklegasta sjúkdómsgreiningin, helstu mismunagreiningar og besta meðferðin?

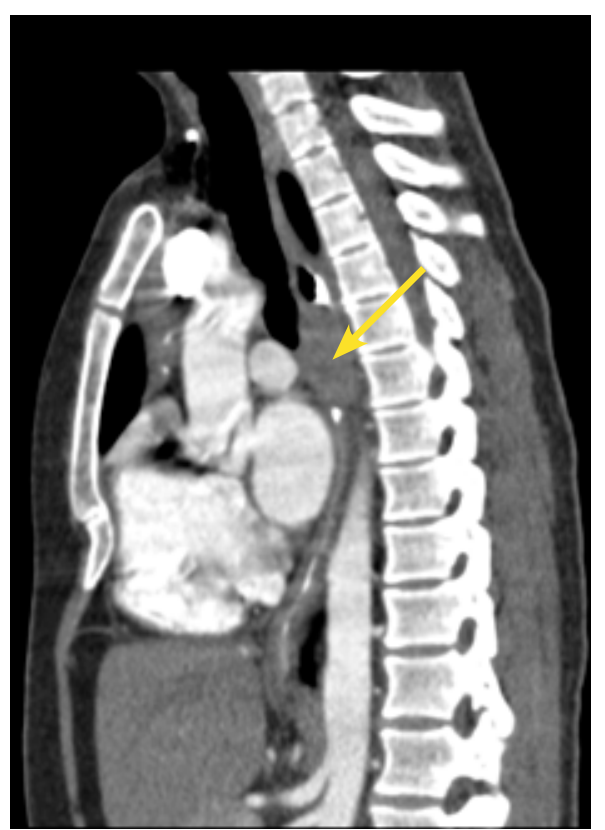

Mynd 1a. Tölvusneiðmynd (pversnið) af æxlinu (ör).

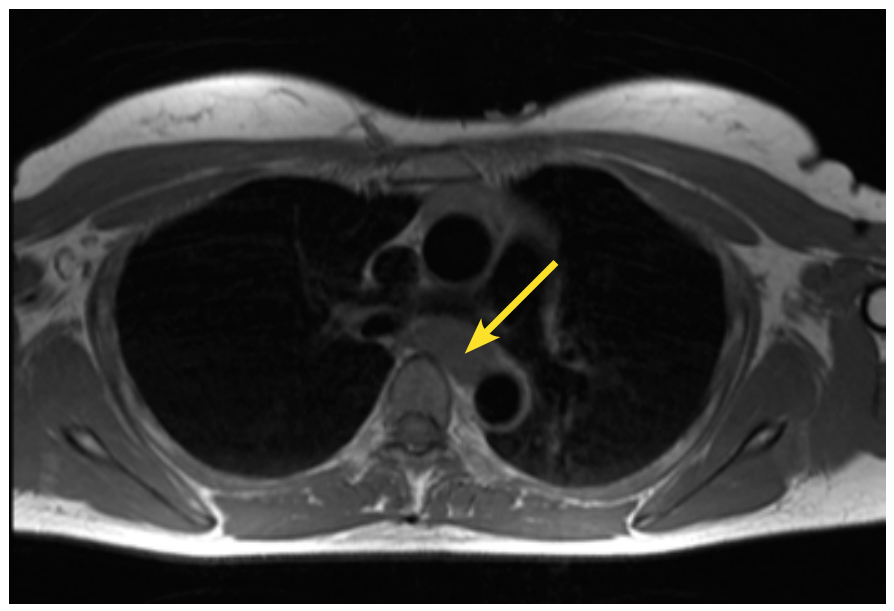

Mynd 1b. Segulómun af æxlinu (ör) 6 mánuðum síðar. 


\section{Svar við tilfelli mánaðarins}

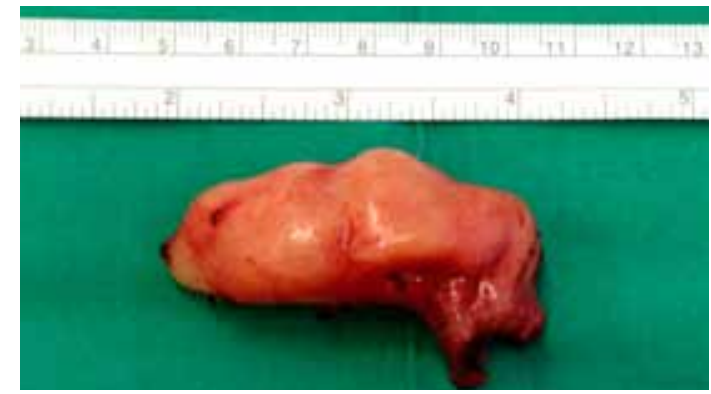

Mynd 2. Æxlið eftir brottnám.

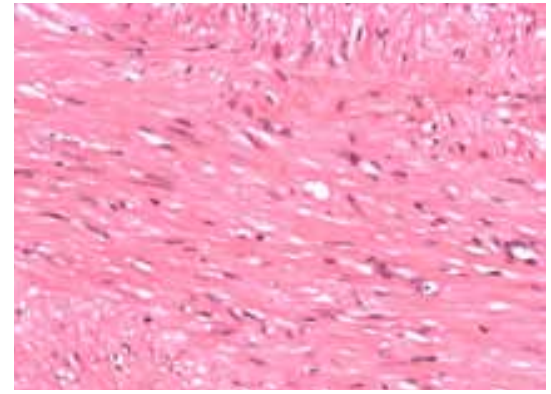

Mynd 3a. Smásjármynd af æxlinu á mynd 2.

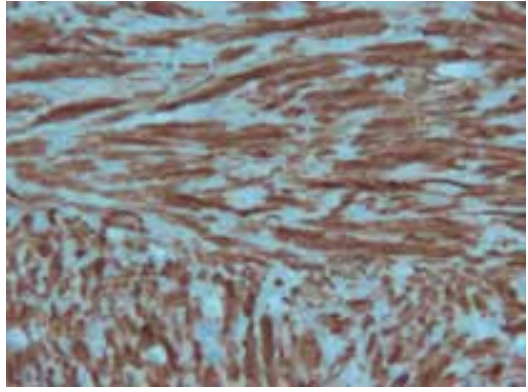

Mynd 3b. Ónæmislitun sem sýnir sterkt jákvæði fyrir desmin og staðfestir að um sléttvöđvaæxli er аð ræðа.
Hér er um að ræða góðkynja sléttvöðvaæxli (leiomyoma) í vélinda. Flest í sögu sjúklings og rannsóknum benti til góðkynja æxlis. Auk pess var æxlið vel afmarkað á tölvusneiðmyndum (mynd 1a) og segulómun gaf til kynna að æxlið væri vaxið útfrá vefjum vélindans (mynd 1b). Endanleg greining fékkst eftir að æxlið hafði verið numið á brott með skurðaðgerð (mynd 2). Í vefjasýni á mynd 3a sjást aðeins fitufrumur og sléttar vöðvafrumur en engar illkynja æxlisfrumur. Með mótefnalitun (desmin) var staðfest að petta væri sléttvöðavæxli (mynd 3a).

Helsta mismunagreiningin er góðkynja fitufrumuæxli (lipoma) eða strómaæxli í meltingarvegi (GIST tumor), fremur en vélindakrabbamein eða sarkmein., ${ }^{1,2}$ Aðrar mismunagreiningar eru meðal annars æxli í hóstarkirtli, fósturkímsæxli (germ cell tumor) og góðkynja blöðrur upprunnar frá skjaldkirtli eða berkjum. ${ }^{1}$

Góðkynja æxli í vélinda eru sjaldgæf, eða um 1-2\% af öllum æxlum í vélinda, og vélindakrabbamein pví margfalt algengari. ${ }^{1,3,4}$ Í 2/3 hluta tilfella góðkynja æxla í vélinda er um að ræða sléttvöðvaæxli (leiomyoma). ${ }^{1}$ Sléttvöðvaæxli vaxa oftast út frá ytra vöðvalagi vélindans (muscularis propria) og ná ekki í gegnum slímubeðinn nema pau sem vaxa frá innra sléttvöðvalaginu (muscularis mucosa). ${ }^{2,5}$ Sléttvöðvaæxli umbreytast afar sjaldan í illkynja æxli. ${ }^{1,3}$ Pau eru ívið algengari hjá körlum en konum, greinast yfirleitt á milli fertugs og fimmtugs og eru oftast staðsett í neðri helmingi vélindans. ${ }^{1,5,6}$ Góðkynja vélindaæxli vaxa yfirleitt hægt og valda oftast ekki einkennum fyrr en æxlið hefur náð $5 \mathrm{~cm} .^{4-6}$ Margir sjúklingar greinast pví fyrir tilviljun, til dæmis á myndgreiningarrannsóknum eða við speglun á efri hluta meltingarvegar. ${ }^{1,7}$

Algengustu kvartanir pessara sjúklinga eru kyngingarerfiðleikar, ónot undir bringubeini eða brjóstverkir og nábítur., ${ }^{1,4}$ Önnur pekkt einkenni en fátíðari eru andpyngsli, hósti og pyngdartap., 2,-6 Kyngingarmynd með skuggaefni var löngum algengasta rannsóknin til greiningar en í dag hafa vélindaspeglun með ómskoðun og tölvusneiðmyndir tekið við. ${ }^{1,5,6}$ Einnig getur komið til greina að gera segulómun eins og gert var í okkar tilfelli. ${ }^{6}$ Á skuggaefnisrannsókn af vélinda getur sést dæmigerð innbungun inn í vélindað með prengingu, ${ }^{1}$ líkt og sést við vélindaspeglun. Vélindaómspeglun sýnir yfirleitt lágpétta fyrirferð í vélindaveggnum. Um leið er mögulegt að ná sýni til vefjagreiningar, sem pó er umdeilt hvort eigi að gera, en sýnin í okkar tilfelli nægðu ekki til greiningar. ${ }^{1}$
Í flestum tilvikum er mælt með pví að fjarlægja sléttvöðvaæxli í vélinda, sérstaklega pau sem valda einkennum og/eða eru stærri en $5 \mathrm{~cm} .1,2,5,6$ Oftast er aðgerðin gerð í gegnum brjóstholsskurð en lýst hefur verið tilfellum par sem notast var við brjóstholssjá (thoracoscopy) og aðgerðarpjarka (robot)., ${ }^{1,2,5}$ Árangur aðgerða er yfirleitt ágætur og dánartíðni innan 30 daga er innan við 2\%. ${ }^{1}$ Algengustu fylgikvillar eftir aðgerð eru bakflæði, kyngingartruflanir, lungnabólga og fleiðruholssýking en hættulegri fylgikvilli er rof á vélinda með miðmætisbólgu. ${ }^{5}$

Eins og áður kom fram var æxlið fjarlægt með skurðaðgerð (mynd 3). Í gegnum hægri brjóstholsskurð tókst að skræla æxlið út úr vélindaveggnum án pess að hol vélindans væri opnað. Lekapróf í aðgerð og skuggaefnisrannsókn fjórum dögum síðar sýndi engin merki um leka og var konan útskrifuð heim til sín viku eftir aðgerð. Hálfu ári eftir aðgerð eru vægar kyngingartruflanir enn til staðar en vélindaspeglun sýnir engin prengsl í vélindanu og eðlilega slímhúð.

Pakkir fá röntgenlæknarnir Maríanna Garðarsdóttir og Auður Sigurbergsdóttir og Helgi J. Ísaksson meinafræðingur, fyrir aðstoð við frágang mynda.

\section{Heimildir}

1. Townsend CM, Beauchamp DR, Evers MB, Mattox KL. Esophagus; Benign tumors and cysts. In: Sabiston Textbook of Surgery (18th edition). Elsevier Saunders, Fíladelfíu 2008: kafli 41.

2. Kent M, d'Amato T, Nordman C, Schuchert M, Landreneau R, Alvelo-Rivera M, et al. Minimally invasive resection of benign esophageal tumors. J Thorac Cardiovasc Surg 2007; 134: $176-81$.

3. Seremetis MG, Lyons WS, deGuzman VC, Peabody JW Jr. Leiomyomata of the esophagus. An analysis of 838 cases. Cancer 1976; 38: 2166-77.

4. Punpale A, Rangole A, Bhambhani N, Karimundackal G, Desai N, de Souca A, et al. Leiomyoma of Esophagus. Ann Thorac Cardiovasc Surg 2007; 13: 78-81.

5. Choong CK, Meyers BF. Benign esophageal tumors: introduction, incidence, classification, and clinical features. Semin Thorac Cardiovasc Surg 2003; 15: 3-8.

6. Mutrie CJ, Donahue DM, Wain JC, Wright CD, Gaissert HA, Grillo HC, et al. Esophageal leiomyoma: A 40-year experience. Ann Thorac Surg 2005; 79: 1122-5.

7. Arnorsson T, Aberg C, Aberg T. Benign tumors of the oesophagus and oesophageal cysts. Scand J Thorac Surg 1984; 18: 145-50.

A female in her forties with dysphagia and chest pain. Esophageal leiomyoma

Arnadottir $\mathrm{H}^{4}$, Gudjonsson $\mathrm{H}^{2}$, Sigurdardottir $\mathrm{M}^{3}$, Blöndal $\mathrm{S}^{4}$, Gudbjartsson $\mathrm{T}^{4}$ ${ }^{1}$ Helsingborgs Lasarett, ${ }^{2}$ Gastrological department, ${ }^{3}$ Pathological division, ${ }^{4}$ Department of Cardiothoracic Surgery Landspítali, The University Hospital in Reykjaviḱk

Key words: Leiomyoma, eosophagus, benign tumor, dysphagia, cheast pain. 